\title{
Ethnobotany and In vitro regeneration of Acorus calamus L. (Acoraceae): a high valued medicinal and economic plant
}

Pratibha Sharma and Jintu Sarma*

Department of Environmental Science, Tezpur University, Napaam, Tezpur, Assam-784028, India.

Received: January 20, 2017; Accepted: January 29, 2017

\begin{abstract}
Acorus calamus $\mathrm{L}$. is a species of enormous medicinal and economic importance. In vitro propagation of this plant was achieved using axillary bud explant. In the present investigation, naturally grown axillary bud and rhizome explants were cultured on standard MS and $\mathrm{B}_{5}$ medium supplemented with different concentration and combination of cytokinines and auxines. The best shoot proliferation was observed in MS medium containing $\mathrm{Kn}(1.0 \mathrm{mg} / \mathrm{l})+\mathrm{IBA}(0.5 \mathrm{mg} / \mathrm{l})$ with $3.33 \pm 0.58$ nos. of Shoots, $7.33 \pm 0.58$ nos. of roots and $15.33 \pm 0.58$ nos. leaves. In $B_{5}$ medium best results found in $\mathrm{Kn}(1.5 \mathrm{mg} /)+\mathrm{NAA}(1.0 \mathrm{mg} / \mathrm{l})$ with $2.67 \pm 0.58$ nos. shoots, $3.67 \pm 0.58$ nos. of roots and11.67 \pm 0.58 nos. of leaves. They were then transplanted in soil: sand: cow dung mixture (1:1:2) and kept in shade for 4 to 5 weeks and then transferred to field for one month. Survival rate was found 80 $\%$ in MS medium and $100 \%$ in $\mathrm{B}_{5}$ medium. The present investigation was carried out with a view to standardize an in vitro culture technique for mass propagation of this important medicinal plant species and was found successful.
\end{abstract}

Key words: Ethnobotany; Micropropagation; Acorus calamus; MS \& $\mathrm{B}_{5}$ medium

\section{Introduction}

Acorus calumus is commonly known as sweet flag of the family Acoraceae. This plant is semi-aquatic, perennial, aromatic herb with creeping rhizomes, growing wild and also cultivated throughout India. In Ayurvedic system of medicine, the rhizomes are used for the treatment of epilepsy and other mental ailments, chronic diarrhoea and dysentery, bronchial catarrh, intermittent fevers and glandular and abdominal tumours, They are also employed for kidney, lever troubles, rheumatism and eczema. The rhizome may have poisonous effect under certain conditions causing disturbed digestion and gastro-enteritis.

Sweet flag oil obtained from roots and leaves was found to possess anti-ulcer and cryoprotective properties. The oil is used in the preparation of aromatic cordials and liquors or flavouring beer and also perfumes (Guenther, 1952). Rhizomes are used for headache, cough asthma and strengthening of teeth and are also used as aphrodisiac (Maithani, 1973). It is also used as an antidote to croton poisoning.

$\begin{array}{ll}\begin{array}{c}\text { Systematic Position } \\ \text { Kingdom }\end{array} & \text { : Plantae } \\ \text { Division } & \text { : Magnoliophyta } \\ \text { Class } & \text { : Monocots } \\ \text { Sub clas } & : \text { Arecidae } \\ \text { Order } & \text { : Acorales } \\ \text { Family: Acoraceae } \\ \text { Genus : Acorus L. } \\ \text { Species } & : \text { A. calamus L. } \\ \text { Syn } & \text { :Acorus griffithii Schott., } \\ & \text { Acorus angustatus Raf., } \\ & \text { Acorus belangeri Schott. }\end{array}$

Common Names and Vernacular Names

(Sylvan and Alvin, 2009)

Commonly known as - sweet flag, calamus, beewort, bitter pepper root, calamus root, flag root, gladdon, myrtle flag, myrtle grass, myrtle root etc. Vernacular name includesAssamese - Boch, Mandarin Chinese- Hangpu, Japanese- Shoubu, Korean -Changpo, Unani- Bacch, HindiBajai, Gora-Bach, Vasa Bach, Marathi -Vekhand, TamilVasambu, Telugu- adaja, Sanskrit -Jatila, Nepali -Bojho.

\section{*Corresponding Author:}

Jintu Sarma,

Department of Environmental Science,

Tezpur University (A Central University),

Napaam, Sonitpur, Assam-784028, India.

E-mail: jsarma88@gmail.com

\section{Ethnobotanical and Medicinal Note}

The sweet flag (Acorus calamus) is extremely used in the Indian medicine. The herb is used both internally as well as externally. In rheumatism, rheumatic fever, inflamed joints, coughs, asthma, epilepsy the plant is highly used (Nadkarni, 2005; Dwivedi et al., 2012). Many workers globally reported many other medicinal activity like Antiseizures Activity (Prisilla et al., 2012), Anti diabetic activity (Gopalakrishna et al., 2010), Antihypertensive Effect (Patel et al., 2012), Anti HIV Activity (Mehrotra et al., 2003), Immuno suppressive Activity (Sandeep et al., 2010), Radio-protection and DNA Repair Activity (Wu et al., 2009), Wound-healing Activity (Jain et al., 2010), Anti-inflammatory Activity (Kim et al., 2009), Synergistic Anthelmintic Activity (Merekar et al., 2011; Xin et al., 2013). The essential oil from rhizomes and its constituent compounds have potential for development into natural fumigants/insecticides (Bhuvaneswari and Chellam, 2009). Anti - bacterial property was also reported by Bhuvaneswari and Balasundaram (2009).

\section{Materials and Methods}

Axillary bud and rhizome was used as explants in case of Acorus calamus. At first collected plant materials were thoroughly washed in running tap water for 10 minutes, and soaked in $1 \%(\mathrm{v} / \mathrm{v})$ commercial detergent (Sodium hypochlorite) with a few drops of extran to remove the dust particles and other surface disinfectants. Then it was washed with sterile double distilled water, rinsed with 70 per cent ethanol. After sterilization the explants were transferred to laminar air flow cabinet under aseptic conditions. The explants were then cut to required sizes and the cut explants $(3-5 \mathrm{~mm}$ in length) were carefully placed in tubes containing semisolid nutrient medium. All these explants were subcultured at regular intervals of time and their growth and development were recorded. After inoculating the tissue onto the culture medium, culture flasks were arranged on culture racks. The temperature of the room was maintained at $25 \pm 1^{\circ} \mathrm{C}$. The light period (16 hrs.) was maintained with the help of an automatic timer. The intensity of light was maintained at 2,500 - 4,000 Lux. The room was sterilized by running an Ozone Generating machine fitted with UV light before keeping the explants.

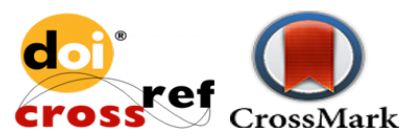


Cultures were examined daily and from the original ones subcultures were made into fresh medium.

The regenerated plantlets with well-developed leaves and roots were transferred to soil in the earthen pots and kept under light and temperature controlled room in an aseptic environment. Rooting media consisted of soil, sand and cow dung (1:1:1) mixture which were sterilized by autoclaving. Before planting to the pot, the plantlets were washed well with sterile distilled water under aseptic conditions and treated with fungicide $(0.1 \%$ Dithane-M- Soln $)$ for 1-2 min. The plants were initially irrigated two times a week, with tap water and sprinkled with MS mineral solution from which they were transferred. After one month of acclimatization they were transferred to glass house where they grew luxuriantly. Then the potted plants were transferred to the field.

\section{Results and Discussion}

In vitro culture of Acorus calamus was carried out with axillary bud explants. Explants were cultured in MS and $\mathrm{B}_{5}$ media, each supplemented with nine different combinations of plant growth regulator with $100 \mathrm{mg} / \mathrm{L}$ of $\mathrm{CH}$. Axillary bud showed better results. Because rhizomatous explants required more time and proved to be more prone to contaminations. In case of medium also, MS medium showed better results than $\mathrm{B}_{5}$ medium. Lower concentrations of kinetin with IBA were effective for regeneration. With kinetin 0.1 and $1.0 \mathrm{mg} / \mathrm{l}$, number of shoots increased and roots started developing gradually with IBA concentrations 0.1 and $0.5 \mathrm{mg} / 1$ in MS medium (Table. 1, Fig. 1A, B, C). The ability of IBA at low concentration in inducing rooting on in vitro culture of plant tissues was also reported (Jawanda et al., 1980; Evaldsson, 1985; Attifield and Evans, 1991; Ahmed et al., 2010).

Table 1: Regeneration of shoots and roots from axillary bud of Acorus calamus on MS medium and $\mathrm{B}_{5}$ medium with different PGRs (Mean 3 \pm SE) and rate of survival.

\begin{tabular}{|c|c|c|c|c|c|c|c|c|c|c|c|}
\hline \multicolumn{4}{|c|}{ PGRs (mg/l) } & \multicolumn{3}{|c|}{$\begin{array}{c}\text { Observation after } 120 \text { days in } \mathrm{MS} \\
\text { medium }\end{array}$} & \multirow{2}{*}{$\begin{array}{l}\text { Rate of } \\
\text { survival }\end{array}$} & \multicolumn{2}{|c|}{ Observation after 120 days in } & \multirow{2}{*}{$\begin{array}{c}\mathrm{B}_{5} \text { medium } \\
\begin{array}{l}\text { No. of } \\
\text { leaves }\end{array}\end{array}$} & \multirow{2}{*}{$\begin{array}{l}\text { Rate of } \\
\text { survival }\end{array}$} \\
\hline Kn & IBA & NAA & BA & $\begin{array}{l}\text { No. of } \\
\text { shoots }\end{array}$ & $\begin{array}{l}\text { No. of } \\
\text { roots }\end{array}$ & $\begin{array}{l}\text { No. of } \\
\text { leaves }\end{array}$ & & $\begin{array}{l}\text { No. of } \\
\text { shoots }\end{array}$ & $\begin{array}{c}\text { No. of } \\
\text { roots }\end{array}$ & & \\
\hline 0.1 & 0.1 & - & - & $3.0 \pm 1.0$ & $5.0 \pm 1.0$ & $13.0 \pm 1.0$ & & & & & \\
\hline 1.0 & 0.5 & - & - & $3.33 \pm 0.58$ & $7.33 \pm 0.58$ & $15.33 \pm 0.58$ & 80 & $1.33 \pm 0.58$ & $3.67 \pm 1.15$ & $7.67 \pm 1.15$ & 100 \\
\hline 1.0 & 0.1 & - & - & $3.0 \pm 1.0$ & $7.0 \pm 1.0$ & $13.0 \pm 1.0$ & 50 & $1.67 \pm 1.15$ & $3.33 \pm 0.58$ & $7.67 \pm 0.58$ & 50 \\
\hline 1.5 & 0.5 & - & - & - & - & - & & $2.33 \pm 0.58$ & $3.67 \pm 0.58$ & $10.67 \pm 1.15$ & 40 \\
\hline 1.5 & 0.1 & - & - & - & - & - & & $2.67 \pm 0.58$ & $3.67 \pm 0.58$ & $11.33 \pm 1.15$ & 100 \\
\hline 0.1 & - & 0.1 & - & $2.0 \pm 1.0$ & $5.0 \pm 1.0$ & $8.0 \pm 1.0$ & 80 & - & -- & - & \\
\hline 0.5 & - & 0.5 & - & $1.67 \pm 0.58$ & $4.0 \pm 1.0$ & $4.43 \pm 0.58$ & 40 & - & - & - & \\
\hline 1.0 & - & 0.5 & - & $2.33 \pm 0.58$ & $4.33 \pm 0.58$ & $7.33 \pm 0.58$ & 50 & - & - & - & \\
\hline 1.5 & - & 0.1 & - & - & - & - & & $1.33 \pm 0.58$ & $3.33 \pm 0.58$ & $6.33 \pm 0.58$ & 100 \\
\hline 1.5 & - & 0.5 & - & $2.67 \pm 0.58$ & $2.23 \pm 0.58$ & $11.33 \pm 1.15$ & 70 & - & - & - & \\
\hline 1.5 & - & 1.0 & - & $4.33 \pm 0.58$ & $6.0 \pm 1.0$ & $15.0 \pm 1.0$ & 80 & $2.67 \pm 0.58$ & $3.67 \pm 0.58$ & $11.67 \pm 0.58$ & 100 \\
\hline 2.0 & - & 0.1 & & - & - & - & & $1.33 \pm 0.58$ & $2.33 \pm 0.58$ & $6.67 \pm 0.58$ & 30 \\
\hline 2.0 & - & 0.5 & - & $2.0 \pm 1.0$ & $3.0 \pm 1.0$ & $11.0 \pm 1.0$ & 50 & $1.67 \pm 1.15$ & $2.33 \pm 0.58$ & $8.33 \pm 0.58$ & 20 \\
\hline- & - & 0.5 & 1.0 & $1.67 \pm 1.15$ & $2.67 \pm 0.58$ & $14.0 \pm 2.0$ & 40 & - & - & - & \\
\hline - & - & 0.1 & 1.5 & $2.67 \pm 0.58$ & $2.67 \pm 0.58$ & $14.0 \pm 1.73$ & 40 & - & -- & - & \\
\hline - & - & 0.5 & 1.5 & $3.0 \pm 1.0$ & $6.0 \pm 1.0$ & $17.0 \pm 1.0$ & 70 & - & - & - & \\
\hline - & - & 2.0 & 4.0 & $4.0 \pm 1.0$ & $5.0 \pm 1.0$ & $21.0 \pm 1.0$ & 70 & - & - & - & \\
\hline- & - & 2.6 & 4.4 & $2.0 \pm 1.0$ & $2.33 \pm 0.58$ & $10.67 \pm 1.15$ & 70 & - & - & - & \\
\hline 1.0 & - & - & - & $2.33 \pm 0.38$ & $3.33 \pm 0.58$ & $8.33 \pm 0.58$ & 60 & - & - & - & \\
\hline 1.5 & - & - & - & $2.33 \pm 0.58$ & $4.33 \pm 0.58$ & $8.33 \pm 0.58$ & 70 & - & - & - & \\
\hline 2.0 & - & - & - & $1.33 \pm 0.58$ & $3.33 \pm 0.58$ & $7.33 \pm 0.58$ & 20 & - & - & - & \\
\hline 2.5 & - & - & - & $2.33 \pm 0.58$ & $4.33 \pm 0.58$ & $7.33 \pm 0.58$ & 30 & - & - & - & \\
\hline- & - & 0.3 & - & $2.67 \pm 0.58$ & $3.67 \pm 0.58$ & $11.67 \pm 0.58$ & 50 & $2.33 \pm 0.58$ & $3.67 \pm 1.15$ & $10.33 \pm 0.58$ & 100 \\
\hline - & - & 0.5 & - & $2.33 \pm 0.58$ & $3.33 \pm 0.58$ & $3.33 \pm 0.58$ & 30 & $2.33 \pm 0.58$ & $3.33 \pm 0.58$ & $8.33 \pm 0.58$ & 80 \\
\hline- & - & 1.0 & - & $1.33 \pm 0.58$ & $2.33 \pm 0.58$ & $4.67 \pm 0.58$ & 70 & $1.33 \pm 0.58$ & $2.33 \pm 0.58$ & $5.33 \pm 0.58$ & 30 \\
\hline - & - & 1.5 & - & - & - & - & & $1.33 \pm 0.58$ & $2.33 \pm 0.58$ & $5.33 \pm 0.58$ & 40 \\
\hline - & - & 2.0 & - & - & - & - & & $1.33 \pm 0.58$ & $3.33 \pm 0.58$ & $6.67 \pm 0.58$ & 20 \\
\hline - & - & 2.5 & - & - & - & - & & $2.33 \pm 0.58$ & $2.33 \pm 0.58$ & $5.53 \pm 0.58$ & 20 \\
\hline - & - & 3.0 & - & - & - & - & & $1.33 \pm 0.58$ & - & $5.53 \pm 0.58$ & 20 \\
\hline - & - & 3.5 & - & - & - & - & & $1.33 \pm 0.58$ & $2.33 \pm 0.58$ & $10.67 \pm 1.15$ & 20 \\
\hline
\end{tabular}

The highest percentage of shoot proliferation was recorded at $1 / 4^{\text {th }}$ MS $+5.7 \mathrm{mg} / 1 \mathrm{IAA}+2.4 \mathrm{mg} / 1 \mathrm{IBA}$ (Patnaik and Debata, 1996). Combination of IAA and IBA showed better results. Best rooting was observed with $1.5 \mathrm{mg} / \mathrm{l} \mathrm{IBA}+1.0 \mathrm{mg} / \mathrm{l} \mathrm{NAA}$. In $\mathrm{B}_{5}$ medium higher concentration of kinetin $1.5 \mathrm{mg} / 1$ with $0.5 \mathrm{mg} / \mathrm{l} \mathrm{IBA}, 2$ shoots per bud developed. In $1.5+0.1 \mathrm{mg} / \mathrm{l}$ kinetin plus IBA, 3 shoots developed with a few rooting (Table. 1, Fig. 1D). In MS, medium Single shoot regenerated in $0.5+0.5 \mathrm{mg} / 1$ kinetin +NAA. Only small callus developed in $1.0+0.1 \mathrm{mg} / \mathrm{l}$ of kinetin and NAA. Multiple shoots developed from axillary buds with $1.5+1.0 \mathrm{mg} / \mathrm{l}$ of kinetin and NAA an average 5 numbers of shoots with root developed from each bud. In other concentrations 2 to 3 shoots were developed. It was also obtained rapid in vitro propagation of Hemidesmus indicus (L) R.Br. on MS medium with kinetin $1.15 \mu \mathrm{M}$ and lower concentration of NAA (0.054 $\mu \mathrm{M})$ (Castillo and Jordan,1997).

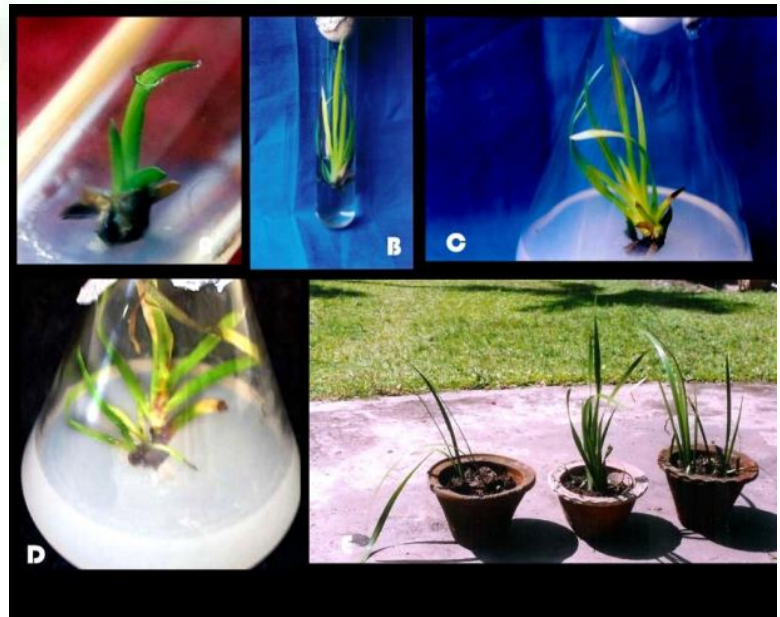

Figure 1. A. Shoot initiations B. shoot development C. shoot multiplications D. Root development E. After hardening transferred to field. 
In $B_{5}$ medium kinetin + NAA $(1.5+1.0 \mathrm{mg} / \mathrm{l})$ concentration 3 shoots per bud developed. Good results were obtained showing well developed shoots with rooting in kinetin $1.5 \mathrm{mg} / \mathrm{l}$ and NAA $1.0 \mathrm{mg} / \mathrm{l}$. Again, explants were tried in the both MS and $\mathrm{B}_{5}$ medium supplemented with kinetin and 2,4-D in various concentrations. The growth of the plantlets was not satisfactory. Hard compact calluses were observed only in $\mathrm{B}_{5}$ medium in the concentration $(0.1+1.0,1.5+0.1 \mathrm{mg} / \mathrm{l})$.

The medium with $4.0 \mathrm{mg} / \mathrm{l}$ of BA with $2.0 \mathrm{mg} / \mathrm{l}$ of NAA, 5 numbers of shoots with roots developed in MS media whereas in $\mathrm{B}_{5}$ medium no development of shoot was observed. Multiple shoots also resulted with a few rooting in some concentrations of $1.0+0.5,1.5+0.1,1.5+0.5$ and $4.4+2.6$ $\mathrm{mg} / \mathrm{l}$ of BA and NAA in MS medium. In MS, medium callus formation was recorded in BA $(3.0 \mathrm{mg} / \mathrm{l})+\mathrm{NAA}(0.5 \mathrm{mg} / \mathrm{l})$. It was reported that shoot growth in MS medium supplemented with higher concentration of $\mathrm{BA}$ and lower concentration of NAA on axillary bud culture of Minthostachys andina, a member of mint family (Das et al., 2004). Best response for shoot multiplication was also obtained on MS basal medium supplemented with $4 \mathrm{mg} / \mathrm{l} \mathrm{BAP}$ and $1.5 \mathrm{mg} / \mathrm{l} \mathrm{NAA}$ for Curcuma caesia and $1 \mathrm{mg} / \mathrm{l} \mathrm{BAP}+0.5 \mathrm{mg} / \mathrm{l} \mathrm{NAA}$ for Curcuma zedoaria (Burger et al., 1985). Also, BA (1mg/l) with NAA (0.1 $\mathrm{mg} / \mathrm{l}$ ) gave best results in axillary bud culture of Paulownia tomentosa (Gangaprasad et al., 2003). However, MS medium containing BAP $(1.0 \mathrm{mg} / \mathrm{l})$ and NAA $(0.01 \mathrm{mg} / \mathrm{l})$ induced formation of maximum number (1.4 per plant) frequency $(90$ per cent) of axillary shoots of $8.7 \mathrm{~cm}$ having 5-7 nodes from nodal segments of Utleria salicifolia (Lilien-Kipnis and Kachba, 1987). Repeated proliferation of apical and lateral buds excised from corms and cormels of six mature Gladiolus hybrids by culturing in MS medium with low levels of NAA and BA or kinetin (Sonmai et al., 1989). The growth of the plantlets was satisfactory on the medium supplemented with BA and NAA. More number of shoots was observed in the concentration BA $(4.0 \mathrm{mg} / \mathrm{l})$ and NAA $(2.0 \mathrm{mg} / \mathrm{l})$ with excellent growth after 120 days. Rooting was also good (Table. 1). Satisfactory results were not observed, when the explants were cultured on $\mathrm{B}_{5}$ medium supplemented with different concentrations of BA and NAA. Responses were very poor throughout the whole experiment. Only small callus development was seen in very lower concentrations of $\mathrm{BA}$ and NAA.

Regeneration was also observed in MS medium supplemented with higher concentration of kinetin alone $(1.0,1.5,2.0$, and $2.5 \mathrm{mg} / \mathrm{l})$ where one and two shoots developed respectively. In $\mathrm{B}_{5}$ medium too response was not good compared to that of MS medium. Regeneration of shoots in kinetin supplemented medium at higher concentration $(2-4 \mathrm{mg} / \mathrm{L})$ was induced on Gloriosa superba (Furuya et al., 1986). In Panax ginseng plantlet formation was promoted by kinetin $(1 \mathrm{ppm})$ from callus (Mao et al., 2002).

The explants exhibited poor respond when cultured on $\mathrm{B}_{5}$ medium with supplementation of kinetin alone. When the MS medium was supplemented with BAP alone in various concentrations, the explants did not show good results. The highest percentage of shoot proliferation was recorded at the treatment of BAP at $3.0 \mathrm{mg}$ lG1 which was $95.86 \%$ (Ahmed $e t$ al., 2007). $\mathrm{B}_{5}$ medium when supplemented with $\mathrm{BAP}$ alone in various concentrations, there was not any satisfactory response in the whole experiment.

Regeneration was possible in both the media supplemented with lower to higher concentrations of NAA alone. Single, double and three shoots with rooting were developed in both the media in concentrations of NAA $(0.1,0.3,0.5,1.0 \mathrm{mg} / \mathrm{l})$.
Lilium mackliniae, a rare endemic and endangered plant produced best bulblets and leaf growth with different type of explants in MS medium supplemented with NAA alone $(0.5 \mu \mathrm{M})$ than in combination with any cytokinin (Lee and Park, 1980)

\section{Transplantation of the plantlets}

After achieving well developed plantlets from the best media (MS and $\mathrm{B}_{5}$ in different concentrations) they were directly transplanted into earthen pots containing sterilized sand and cow dung. Required numbers of earthen pots (Fig. 1E) were prepared and plantlets were transplanted in each pot. The potting media were moistened with the respective mineral media without sugar and agar. For acclimatization, plantlets were kept inside the laboratory for one month with 70 per cent humidity, $25 \pm 1^{\circ} \mathrm{C}$ temperature and higher light intensity regimes (3000-4000 lux). Then the plantlets were sprayed with water twice a week.

\section{Percentage of survival of the plantlets}

After 120 days from the time of culture, plantlets were taken out of flasks and transferred to soil. Best culture obtained in MS medium with suitable regenerating medium concentrations were $1.0+0.5 \mathrm{mg} / \mathrm{Kn}+\mathrm{IBA}$ and $0.1+0.1 \mathrm{mg} / \mathrm{l} \mathrm{Kn}$ and NAA, showed $80 \%$ survival rate. $B_{5}$ medium with favourable regenerating medium concentrations were $1.0+0.5,1.5+0.1$ $\mathrm{mg} / \mathrm{l} \mathrm{Kn}+\mathrm{IBA}, 1.5+0.1 \mathrm{mg} / \mathrm{l}, 1.5+1.0 \mathrm{mg} / \mathrm{l} \mathrm{Kn}+\mathrm{NAA}$ and $0.3 \mathrm{mg} / \mathrm{l} \mathrm{NAA}$ alone respectively (Table. 1). The plantlets derived from these concentrations are high in number and showed 100 per cent of survival in soil.

\section{Conclusion}

From the note, it is crystal clear that Acorus calamus has enormous ethnobotanical value. Considering its importance multiplication through in vitro process was very impressive from commercial and medicinal point of view and was found very successful. After successful experiments with lots of combinations of plant growth regulators with $\mathrm{MS}$ and $\mathrm{B}_{5}$ media, it has been found that MS medium supplemented with $\mathrm{Kn}(1.0 \mathrm{mg} / \mathrm{l})+\mathrm{IBA}(0.5 \mathrm{mg} / \mathrm{l})$ resulted $80 \%$ survival rate in field and $\mathrm{In} \mathrm{B}_{5}$ medium best results found in $\mathrm{Kn}(1.5 \mathrm{mg} / \mathrm{l})+$ NAA $(1.0 \mathrm{mg} / \mathrm{l})$ with $100 \%$ survival rate.

\section{Abbreviations}

MS: Murashige and Skoog (1962) medium, B 5 (Gamborg et al. 1968) BA: N6 Benzyladenine, IBA: Indole-3-Butyric Acid, IAA: Indole-3-Acetic Acid, NAA: Naphthelene Acetic Acid, Kn: Kinetin.

\section{Acknowledgements}

The authors are thankful to the Tezpur University and Department of Botany Gauhati University for providing necessary facilities for conducting the experiments.

\section{References}

1. Guenther E, The essential oils, Dvan Nostrand Company Inc., New York, 1952,4, 109

2. Maithani BP, Medicinal Plants of Western Garhwal, Khadi Gramodyog, 1973, 19, 269-278

3. Sylvan TR, Alvin F, Bull Wildflowers of Iowa Woodlands. Iowa City, Iowa: University of Iowa Press, 2009, 119.

4. Nadkarni KM, Indian Plants and Drugs with their medicinal properties and Uses, Srishti Book Distributors, New Delhi, 2005.

5. Dwivedi P, Singh R, Malik MT, Jawaid T, A traditional approach to herbal Nootropic agents: An overview. Int. J Pharm Sci. Res., 2012, 3, 630-6. 
6. Prisilla $\mathrm{DH}$, Balamurugan $\mathrm{R}$, Shah $\mathrm{HR}$, Ant diabetic activity of methanol extract of Acoruscalamus in STZ induced diabetic rats, Asian Pac J Trop Biomed., 2012, 2, 941.

7. Gopalakrishna HN, Sudhakar P, Shilin G, Shenoy AK, Holla, GK, Nair V, Alwar MC, Sheethal U, Effect of Acorus calamus on electrical and chemical induced seizures in mice. Int $\mathrm{J}$ Appliolo Pharma Technol., 2010,1, 465-72.

8. Patel P, Vaghasiya J, Thakor A, Jariwala J, Antihypertensive effect of rhizome part of Acoruscalamus on renal artery occlusion induced hypertension in rats. Asian Pac J Trop Dis., 2012, 1, 6-10.

9. Mehrotra S, Mishra KP, Maurya R, Srimal RC, Yadav VS, Pandey R, Singh VK, Anticellular immunosuppressive properties of ethanolic extract of Acorus calamus rhizome. Int Immuno pharmacol., 2003, 3,53-61.

10. Sandeep D, Nair CK, Radioprotection by Acoruscalamus: Studieson in vivo DNA damage and repair. Int J Low Radiat., 2010,7,121-32.

11. Wu HS, Zhu DF, Zhou CX, Feng CR, Lou YJ, Yang B, He QJ, Insulin sensitizing activity of ethyl acetate fraction of Acorus calamus $\mathrm{L}$. in vitro and in vivo. J Ethnopharmacol., 2009, 123,288-92

12. Jain N, Jain R, Jain A, Jain DK, Chandel HS, Evaluation of wound-healing activity of acoruscalamus Linn. Nat Prod Res., 2010, 24,534-41.

13. Kim H, Han TH, Lee SG, Anti-inflammatory activity of a water extract of Acoruscalamus L. leaves on keratinocyte HaCaT cells., J Ethnopharmacol., 2009,122,149-56.

14. Merekar AN, Pattan SR, Parjane SK, Nirmal SA, Patel DS, Shitre MR, Synergistic Anthelmintic activity of rhizomes of Acoruscalamus and roots of Vitexnegundo. Pharmacologyonline ,2011,3, 209-212.

15. Xin Chao Liu, Li Gang Zhou, Zhi Long Liu, and Shu Shan Du, Identification of Insecticidal Constituents of the Essential Oil of Acoruscalamus Rhizomes against Liposcelis bostrychophila Badonnel, Molecules, 2013, 18, 5684-5696.

16. Bhuvaneswari R, Chellam B, Anti-bacterial activity of Acoruscalamus and some of its derivates against fish pathogen Aeromonashydrophila, Journal of Medicinal Plants Research, 2009, 3, 538-547.

17. Jawanda JS, Jossan JS, Singh SN, Propagation of Prunussps. by cuttings. I. Effect of IBA and the type of peach cuttings on rootings, J. Res., 1979,16, 408-412.

18. Jawanda JS, Jossan JS, Singh SN, Propagation of Prunussps. by cuttings. II. Effect of IBA and the type of cuttings on rooting in plum, J. Res., 1980, 17, 17-21.

19. Evaldsson I, Induction, growth and differentiation of callus from stem segments of in vitro cultured apple shoots (Malus domestica Borkh), Swedish J. Agri. Res., 1985, 15, 119-122.
20. Attifield EM, Evans PK, Stages on the initiation of root and shoot organigenesis in cultured leaf explants of Nicotiana tabacum cv. Xanthinic, J. Exp. Bot., 1991, 42, 59-63.

21. Ahmed A, Shashidhara S, Rajasekharan PE, Hareesh Kumar V, Honnesh NH, In vitro regeneration of Acorus Calamus - an important medicinal plant, Journal of Current Pharmaceutical Research, 2010, 2, 36-39.

22. Patnaik J, Debata BK, Micropropagation of Hemidesmus indicus (L) R.Br. through axillary bud culture, Plant Cell Rep., 1996,15, 427-430.

23. Castillo JA, Jordan M, In vitr regeneration of Minthostachys andina(Brett) Epling- a Bolivian native species with aromatic and medicinal properties, Plant Cell Tiss. Org. Cult., 1997, 49, 157-160.

24. Das A, Bharalee R, Kalita MC, In vitro micropropagation of Curcuma caesia Roxb.andCurcuma zeoaria Rose.from bud explants. In: Abst. National Seminar on Medicinal Plant in North-Eastern Region., Govt. Ayurvedic College, Guwahati, 2004

25. Burger DW, Liu L, Wu L, Rapid micropropagation of Paulownia tomentosa, Hort. Sci., 1985,20, 760-761.

26. Gangaprasad A, Nair Lakhmi G, Radhakrishnan K, Seeni S, Nair GM, Pushpangadan P, Micropropagation of Utleria salicifolia endemic and endangered ethnomedicinal plant of Western Ghats, J. Med. Aro. Pl. Sci.,2003, 25, 19-24

27. Lilien-Kipnis $\mathrm{H}$, Kachba M, Mass propagation of new Gladiolus hybrids, Acta. Hort.,1987, 212, 631-638.

28. Sonmai VJ, John CK, Thengane RJ, In vitro propagation and corm formation in Gloriosa superba L., Ind. J. Exp. Biol., 1989, 27, 57805789.

29. Furuya M, Yoshikana T, Usluyama K, Oda H, Formation of plantlets from callus cultures of ginseng (Panax ginseng), Experientia,1986,42, 193-194.

30. Mao AA, Wetten A, Fay MF, Caligari PDS, In vitro culture of Liliummackliniae Sealy, a rare endemic species, Ind. J. Plant Physiol, $2002,7,239-245$.

31. Ahmed MB, Ahmed S, Salahin M, Sultana R, Khatun M, Razvy MA, Standardization of a Suitable Protocol for in vitro Clonal Propagation of AcoruscalamusL. an Important Medicinal Plant in Bangladesh, American-Eurasian Journal of Scientific Research, 2007, 2, 136-140.

32. Lee JB, Park MO, Organ formation on axillary buds of Strawberry in in vitro culture. I. Effect of $\mathrm{BA}, \mathrm{NAA}$ and 2, 4-D on the formation of shoot and callus from axillary bud's in vitro culture, J. Kor. Soc. Hortic. Sci., 1980, 21, 3-17.

\section{Cite this article as:}

Pratibha Sharma and Jintu Sarma. Ethnobotany and In vitro regeneration of Acorus calamus L. (Acoraceae): a high valued medicinal and economic plant. Annals of Plant Sciences 6.02 (2017): 1568-1571. DOI: http://dx.doi.org/10.21746/aps.2017.02.006 